\title{
Analisis Permintaan Konsumsi Cabai Rawit pada Rumah Tangga di Kota Mataram
}

\author{
Dudi Septiadi ${ }^{\mathrm{a}}$, Ni Made Wirastika Sari ${ }^{\mathrm{b}}$, dan Ahmad Zainuddin ${ }^{\mathrm{c}}$ \\ ${ }^{a}$ Fakultas Pertanian, Universitas Mataram,-NTB, Indonesia.Email: dudi@unram.ac.id \\ ${ }^{b}$ Fakultas Pertanian, Universitas Mataram,-NTB, Indonesia.Email: wirastikasari@unram.ac.id \\ ${ }^{c}$ Fakultas Pertanian, Universitas Jember,- Jawa Timur, Indonesia. Email: : zainuddin91.faperta@unej.ac.id
}

\section{Article Info}

\section{Article history:}

Received 3 Maret 2020

Received in revised form 13 Maret 2020

Accepted 20 April 2020

DOI:

https://doi.org/10.32938/ag.v5i2.1023

Keywords:

Cabai Rawit

Konsumsi

Permintaan

$\underline{\text { Rumah Tangga }}$

\section{Abstrak}

Penelitian ini bertujuan untuk 1) menganalisis karakteristik konsumen cabai rawit di Kota Mataram; dan 2) menganalisis faktor - fakto yang mempengaruhi permintaan cabai rawit di Kota Mataram. Penelitian ini dilakukan di Pasar Kebun Roek, Pasar Pagesangan, dan Pasa Tanjung Karang Kota Mataram, Provinsi Nusa Tenggara Barat. Responden yang digunakan ditentukan secara kuota sampling sebanyak 30 Sampel dengan teknik pengambilan sampel secara accidental sampling. Metode analisis yang digunakan adalah metode analisis deskriptif kualitatif dan analisis kuantitatif dengan menggunakan analisis regresi linier berganda. Hasil penelitian menunjukkan bahwa karakteristik konsumen cabai rawit pada penelitian ini sebanyak 100 persen adalah berjenis kelamin perempuan. Jumlah responden yang berusia pada rentang umur 15 - 64 tahun sebanyak 100 persen. Responden yang menyelesaikan pendidikan pada tingkat Perguruan Tinggi sebanyak 63,33 persen. Responden yang berprofesi sebagai Ibu rumah tangga sebanyak 36,66 persen. Responden yang memiliki jumlah anggota keluarga sejumlah 3 anggota sebanyak 46,66 persen. Hasil penelitian menunjukkan variabel harga cabai rawit dan variabel jumlah anggota keluarga memiliki pengaruh yang signifikan terhadap permintaan cabai rawit di Kota Mataram.

\section{Pendahuluan}

Sektor pertanian merupakan salah satu sektor andalan dalam pembentuk PDB berdasarkan lapangan usaha (Septiadi dan Joka, 2019). Cabai rawit merupakan salah satu komoditas hortikultura yang banyak dibudidayakan oleh petani di Indonesia (Priyadi, 2017). Permintaan ketersediaan cabai rawit di Indonesia setiap tahunnya mengalami peningkatan seiring dengan meningkatnya jumlah penduduk serta tumbuhnya industri pengolahan cabai rawit (Kementrian Pertanian, 2017)

Cabai rawit merupakan salah satu jenis komoditas hortikultura unggulan nasional. Berdasarkan Survei Sosial Ekonomi Nasional (SUSENAS) Secara agregatif konsumsi cabai rawit pada tahun 2013 sebanyak 316,57 ribu ton per tahun. Kemudian kebutuhan konsumsi pada tahun 2014 mengalami peningkatan sebesar 318,21 ribu ton per tahun (BPS, 2017). Tingginya permintaan cabai rawit dikarenakan cabai rawit merupakan komoditas pertanian yang mengandung zatzat gizi yang sangat diperlukan untuk kesehatan manusia (Bete dan Taena, 2018) Menurut Warisno (2010) dan Maulana (2015) kebutuhan cabai rawit di Indonesia sebanyak $4 \mathrm{~kg} / \mathrm{kapita} / \mathrm{tahun}$. Hal ini tidak terlepas dari banyaknya jumlah penduduk serta berkembangnya sektor industri yang membutuhkan bahan baku cabai rawit.

Provinsi Nusa Tenggara Barat merupakan provinsi terbesar kedua sebaga penghasil cabai rawit setelah provinsi Jawa Timur, Provinsi NTB pada tahun 2018 berhasil memproduksi 210.530 Ton cabai rawit (BPS, 2019). Jumlah pengeluaran makanan per kapita di Kota Mataram pada tahun 2018 adalah $\mathrm{Rp}$ 693.934/bulan yang termasuk cabai rawit di dalamnya (BPS, 2018). Angka tersebut cukup tinggi, hal ini juga didukung secara sosiologis masyarakat di NTB umumnya dan secara khusus Kota Mataram memiliki selera makanan dengan citarasa pedas yang tinggi. Hal ini tentu berimplikasi pada permintaan rumah tangga untuk konsumsi akan komoditas cabai rawit yang juga terus meningkat.

Potensi permintaan cabai rawit di Kota Mataram cukup tinggi, sehingga ini menjadi peluang bagi para produsen cabai rawit yang sebagian besar berasal dari kabupaten di luar Mataram di Provinsi Nusa Tenggara Barat. Masyarakat Kota Mataram pada umumnya membeli cabai rawit di pasar tradisional dan pasar modern. Berdasarkan pengamatan studi pendahuluan, sebagian besar konsumen cabai rawit yang di dominasi ibu rumah tangga relatif lebih memilih membeli cabai rawit di pasar tradisional dikarenakan faktor harga yang lebih bisa dijangkau konsumen dibandingkan dengan membeli di pasar modern (Data Primer, 2019). Hanya saja perkembangan harga cabai rawit di pasar tradisional sangat dinamis dan cenderung tidak menentu. Cabai rawit dikatakan sebagai salah satu komoditi pertanian yang harganya sangat fluktuatif dan bahkan memiliki daya agresifitas dalam mempengaruhi inflasi. Cabai rawit tercatat sebagai salah satu komoditi yang memberikan sumbangan sebesar 2,09 persen terhadap pembentukan inflasi di Kota Mataram pada bulan Desember 2017 (BPS Provinsi NTB, 2018).

Menurut Zaini (2014) pengaruh harga cabai rawit terhadap inflasi cukup tinggi, karena harga cabai rawit sifatnya yang sering berfluktuasi secara tajam tersebut maka cabe merupakan komoditi penyumbang penting laju inflasi daerah (termasuk Mataram). Hal ini menyebabkan permintaan cabai rawit di Kota Mataram menjadi hal yang menarik untuk diteliti. Faktor - faktor yang mempengaruhi permintaan rumah tangga terhadap cabai rawit tidak hanya ditentukan oleh harga komoditi itu sendiri. Namun juga ditentukan oleh harga komoditi yang berkaitan (Noviasari, 2014). Komoditas lain yang juga mempengaruhi permintaan caba rawit di Kota Mataram yaitu cabai rawit organik, cabai merah besar dan bawang merah. Faktor sosial ekonomi seperti pendapatan keluarga dan jumlah anggota keluarga juga diduga kuat memiliki pengaruh terhadap permintaan rumah tangga terhadap konsumsi cabai rawit.

Berdasarkan penjelasan tesebut, maka isu tentang faktor penentu permintaan cabai rawit menjadi tema yang menarik untuk diteliti lebih lanjut. Berdasarkan uraian-uraian tersebut, maka tujuan penelitian ini adalah; 1) menganalisis karakteristik konsumen cabai rawit di Kota Mataram; dan 2) menganalisis faktor-faktor yang mempengaruhi permintaan konsumen terhadap cabai rawit di Kota Mataram.

\section{Metode}

\subsection{Lokasi dan Waktu Penelitian}

Penelitian ini dilakukan di Pasar Kebun Roek, Pasar Pagesangan, dan Pasar Tanjung Karang Kota Mataram, Provinsi Nusa Tenggara Barat. Pemilihan Lokasi penelitian dilakukan secara sengaja karena ketiga pasar tersebut merupakan pasar tradisional terbesar di Kota Mataram. Penelitian dilakukan mulai Oktober 2019 sampai dengan Januari 2020.

\subsection{Data dan Metode pengumpulan Data}

Data dalam Penelitian ini berupa data Kuantitatif dan Kualitataif yang diperoleh dari sumber primer dan sumber sekunder. Metode pengumpulan data yang dipakai adalah observasi, wawancara dan dokumentasi.

\subsection{Populasi dan Sampel}

Populasi yang digunakan dalam penelitian ini adalah Konsumen Rumah tangga yang membeli cabai rawit di Pasar Kebun Roek, Pasar Pagesangan, dan Pasar Tanjung Karang untuk kebutuhan rumah tangganya sendiri. Sampel yang dipilih merupakan konsumen ibu rumah tangga, yang membeli cabai rawit untuk memenuhi kebutuhan rumah tangganya sendiri dan bukan untuk keperluan perdagangan maupun keperluan lainnya. Jumlah Sampel yang digunakan ditentukan secara Kuota Sampling sebanyak 30 Sampel dengan teknik pengambilan sampel secara accidental sampling, dimana dipilih 10 responden pada setiap lokasi pasar.

\subsection{Variabel Penelitian}

Konsep variabel yang digunakan pada penelitian ini merupakan variabel bebas yang diduga berpengaruh terhadap permintaan cabai rawit (variabel terikat). Variabel bebas dalam penelitian ini meliputi harga cabai rawit $\left(\mathrm{X}_{1}\right)$ harga cabai merah besar $\left(\mathrm{X}_{2}\right)$, harga cabai rawit organik $\left(\mathrm{X}_{3}\right)$, harga bawang merah $\left(\mathrm{X}_{4}\right)$, jumlah anggota keluarga $\left(\mathrm{X}_{5}\right)$, dan pendapatan rumah tangga $\left(\mathrm{X}_{6}\right)$.

\subsection{Metode Analisis data}

Metode analisis data yang digunakan pada penelitian ini adalah analisis deskriptif kualitatif dan analisis kuantitatif. Untuk mengetahui dan menganalisis karakteristik konsumen cabai rawit di Kota Mataram digunakan metode analisis deskriptif kualitatif (Sugiyono, 2006). Faktor- faktor yang mempengaruh permintaan konsumen terhadap cabai rawit di Kota Mataram dianalisis menggunakan metode analisisi regresi berganda dengan metode kuadrat terkeci (Ordinary Least square) (Gujarati \& Porter, 2009). Secara matematis fungsi permintaan cabai rawit dapat di tuliskan sebagai berikut:

$$
\hat{\mathbf{Y}}=\mathbf{a}+\mathbf{b}_{1} \mathbf{X}_{1}+\mathbf{b}_{2} \mathbf{X}_{2}+\mathbf{b}_{3} \mathbf{X}_{3}+\mathbf{b}_{4} \mathbf{X}_{4}+\mathbf{b}_{5} \mathbf{X}_{5}+\mathbf{b}_{6} \mathbf{X}_{6}+\varepsilon
$$

dimana:

= Jumlah permintaan cabai rawit (kg/bulan)

$\mathrm{X}_{1} \quad=$ Harga cabai rawit $(\mathrm{Rp} / \mathrm{kg})$

$\mathrm{X}_{2} \quad=$ Harga cabai rawit organik $(\mathrm{Rp} / \mathrm{kg})$

$\mathrm{X}_{3} \quad=$ Harga cabai merah besar $(\mathrm{Rp} / \mathrm{kg})$

$\mathrm{X}_{4} \quad=$ Harga bawang merah $(\mathrm{Rp} / \mathrm{kg})$

$\mathrm{X}_{5} \quad=$ Jumlah anggota keluarga (orang/RT)

$\mathrm{X}_{6} \quad=$ Pendapatan rumah tangga ( $\mathrm{Rp} /$ bulan)

$\begin{array}{ll}\mathrm{X}_{6} & =\text { galat } \\ \varepsilon & \end{array}$

a $\quad=$ konstanta

$\mathrm{b}_{1}-\mathrm{b}_{6} \quad=$ Koefisien regresi

Untuk mengestimasi persamaan regresi linier berganda tesebut perlu dilakukan uji statistik. Diantaranya yaitu; Uji koefisien determinasi (R-Square), Uji F-Statistik, dan Uji T-Statistik.

2.6. Uji Asumsi klasik

Pada model penelitian dilakukan uji asumsi klasik, diantaranya adalah uji normalitas, uji multikoliniearitas, uji heteroskedastisitas dan uji autokorelasi.s 


\section{Uji Normalitas}

Tujuan dilakukannya uji normalitas adalah untuk menguji apakah variabel penganggu (error term) memiliki distribusi normal atau tidak Berdasarkan uji normalitas menggunakan histogram normality test dengan nilai Jarque-Bera sebesar $0,7714692>$ dari taraf nyata 0,10 (10 persen). Artinya data yang dihimpun pada penelitian ini memiliki data yang terdistribusi secara normal.

2. Uji Multikolinieritas

Uji multikolinieritas digunakan untuk melihat keeratan hubungan antar variabel bebas yang dibangun pada model. Pada penelitian ini hasil uji multikolinieritas ditunjukkan pada tabel 1 .

3. Uji Heteroskedastisitas

Heteroskedastisitas muncul apabila kesalahan (error) atau residual dari model yang diamati tidak memiliki varians yang konstan dari satu observasi ke observasi lainnya. Artinya uji heteroskedastisitas dilakukan untuk melihat apakah nilai residual dari model yang diamati memiliki varians yang konstan dari satu observasi ke observasi lainnya. Uji heteroskedastisitas penelitan in menggunakan uji breusch pagan godfrey. Hasil uji heterskodastisatas dapat diliat pada tabel 2 .

Tabel 1. Hasil Uji Korelasi

\begin{tabular}{lcccccc}
\hline \multicolumn{1}{c}{ Variabel } & $\begin{array}{c}\text { Harga } \\
\text { Cabai } \\
\text { Rawit }\end{array}$ & $\begin{array}{c}\text { Harga } \\
\text { Cabai } \\
\text { Rawit } \\
\text { Organik }\end{array}$ & $\begin{array}{c}\text { Harga } \\
\text { Cabai } \\
\text { Merah } \\
\text { Besar }\end{array}$ & $\begin{array}{c}\text { Harga } \\
\text { Bawang } \\
\text { Merah }\end{array}$ & $\begin{array}{c}\text { Jumlah } \\
\text { Anggota } \\
\text { Keluarga }\end{array}$ & Pendapatan \\
\hline $\begin{array}{l}\text { Harga cabai } \\
\text { rawit }\end{array}$ & 1 & -0.0068 & 0.1908 & 0.0131 & -0.4100 & 0.2833 \\
$\begin{array}{l}\text { Harga cabai } \\
\text { rawit organik }\end{array}$ & -0.0068 & 1 & 0.0384 & 0.4438 & 0.2974 & 0.2398 \\
$\begin{array}{l}\text { Harga cabai } \\
\text { merah besar }\end{array}$ & 0.1908 & 0.0384 & 1 & 0.0557 & -0.0318 & 0.1116 \\
$\begin{array}{l}\text { Harga } \\
\text { bawang } \\
\text { merah }\end{array}$ & 0.0131 & 0.4438 & 0.0557 & 1 & -0.0176 & 0.0915 \\
$\begin{array}{l}\text { Jml anggota } \\
\text { keluarga }\end{array}$ & -0.4100 & 0.2974 & -0.0318 & -0.0176 & 1 & 0.0933 \\
$\begin{array}{l}\text { Pendapatan } \\
\text { Sumber: Output E- Views-9(2019) }\end{array}$ & 0.2833 & 0.2398 & 0.1116 & 0.0915 & 0.0933 & 1 \\
\hline
\end{tabular}

Tabel 2. Heteroskedasticity Test: White

\begin{tabular}{cccc}
\hline F-statistic & 1.147944 & Prob. F(27,2) & 0,5710 \\
\hline Obs*R-squared & 28.18151 & Prob.Chi-Square(27) & 0.4017 \\
\hline Scaled explained SS & 10.78513 & Prob.Chi-Square(27) & 0.9977 \\
\hline Sumber: Output E-Views-9(dia) & &
\end{tabular}

Berdasarkan tabel 2, dapat dilihat nilai Obs R-squared sebesar 28.18151 lebih besar dari nilai taraf nyata 0,10 (10 persen), artinya model yang dibangun pada model penelitian ini terbebas dari masalah heteroskedastisitas.

\section{Uji Autokorelasi}

Uji Autokorelasi digunakan untuk melihat apakah ada korelasi antara variabel error term pada satu periode tertentu dengan variabel error pada periode lain. Sehingga asumsi terbebasnya model dari masalah autokorelasi ditunjukkan oleh nilai error yang mempunyai rata-rata nol dengan variannya konstan. Uji korelasi pada penelitian ini menggunakan pendekatan Breusch-Godfrey Serial Correlation LM Test. Hasil uji autokorelasi dapat dijelaskan pada tabel 3.

Tabel 3. Hasil uji Breusch-Godfrey Serial Correlation LM Test:

\begin{tabular}{llll}
\hline F-statistic & 1.594495 & Prob. F(2,21) & 0.2266 \\
\hline Obs*R-squared & 3.955093 & Prob. Chi-Square(2) & 0.1384 \\
\hline Sumber: Output E-Views-9 (diolah) & &
\end{tabular}

Berdasarkan Tabel 3, dapat dilihat bahwa nilai Prob. Chi-Square sebesar 0,1384 lebih besar dari taraf nyata 0,10 (10 persen), artinya model yang dibangun pada penelitian ini terbebas dari masalah autokorelasi.

\section{Hasil dan Pembahasan}

\subsection{Karekteristik Responden}

Karakteristik responden merupakan bagian penting dalam penelitian Karakteristik responden dari suatu penelitian dapat mengetahui keadaan responden. Responden dalam penelitian ini adalah masyarakat yang bertempat tinggal di Kota Mataram. Khususnya responden yang bertempat tinggal di dekat lokasi penelitian kami yaitu di sekitar Pasar Pagesangan, Pasar Tanjung Karang Perumnas dan Pasar Kebon Roek. Karakteristik Responden yang mengonsumsi cabai rawit di Kota Mataram diantaranya adalah sebagai berikut;

\section{a. Kisaran Usia Responden}

Berdasarkan Tabel 4, klasifikasi responden didasarkan berdasarkan umur. Menurut Adianto dan Fedryansyah (2018) Penduduk tergolong tenaga kerja jika penduduk tersebut telah memasuki usia kerja. Di Indonesia, batas usia kerja yang berlaku adalah umur 15 tahun - 64 tahun. Sedangkan Penduduk pada usia $<15$ tahun dan berusia $>64$ termasuk penduduk dengan kategori bukan tenaga kerja.
Berdasarkan tabel 4 , kisaran umur responden yang berusia $<15$ tahun dan berusia $>64$ tahun sebesar 0 persen. Sedangkan yang berusia $15-64$ tahun di peroleh sebesar 100 persen. Hasil ini menjelaskan bahwa tidak ada konsumen cabai rawit di rentang umur $<15$ tahun dan rentang umur $>64$ tahun. Konsumen cabai rawit di kota mataram didominasi oleh masyarkat pada rentang usia 15 64 tahun.

Tabel 4. Usia Responden Konsumen Cabai Rawit di kota Mataram

\begin{tabular}{lcc}
\hline Umur & Jumlah & Presntase $(\%)$ \\
\hline$<15$ tahun & 0 & 0 \\
$15-64$ tahun & 30 & 100 \\
$>64$ tahun & 0 & 0 \\
\hline Jumlah & 30 & 100 \\
\hline
\end{tabular}

Sumber: Data primer (2019)

\section{b. Tingkat Pendidikan}

Tingkat Pendidikan seseorang akan menentukan seberapa besar pengetahuan yang dimilikinya. Pendidikan juga sangat diperlukan untuk memasuki dunia kerja. Tingginya Pendidikan seseorang juga akan menentukan kesempatan memperoleh jenis pekerjaan yang layak.

Tipologi masyarakat Kota Mataram merupakan masyarakat perkotaan Kesadaran akan pentingnya pendidikan sudah cukup tinggi. Semakin tinggi pendidikan semakin tinggi pula pengetahuan akan kesehatan dan gizi keluarganya (Amirudin dan Nurhayati, 2014). Tingginya kesadaran akan pengetahuan akan kesehatan dan gizi berimplikasi pada tingginya kesadaran untuk mengkonsumsi sayur-mayur sebagai sumber gizi, termasuk cabai rawit $\mathrm{d}$ dalamnya. Tingkat pendidikan responden konsumen cabai rawit di kota Mataram dapat dilihat pada tabel berikut ini

Tabel 5. Tingkat pendidikan responden konsumen cabai rawit di kota Mataram

\begin{tabular}{lcc}
\hline Pendidikan & Jumlah & Persentase (\%) \\
\hline Tidak Sekolah & 0 & 0 \\
SD & 2 & 6,66 \\
SMP & 4 & 13,34 \\
SMA & 5 & 16,66 \\
Perguruan Tinggi & 19 & 63,34 \\
\hline Jumlah & 30 & 100 \\
\hline
\end{tabular}

Sumber: Data primer (2019)

Berdasarkan Tabel 5, untuk tingkat Pendidikan diperoleh yang tidak bersekolah ( 0 persen), tamat SD 2 orang $(6,66$ persen), tamat SMP 4 orang $(13,34$ persen), tamat SMA 5 orang (16,66 persen), dan yang tamat Perguruan Tinggi sebanyak 19 orang dengan presentase (63,34 persen). Responden pada penelitian ini banyak yang memiliki tingkat pendidikan yang tinggi, sebanyak 80 persen responden mengenyam pendidikan SMA dan Perguruan Tinggi. Artinya konsumen cabai rawit pada penelitian ini sebagian besar merupakan konsumen terdidik. Menurut Rahardja \& Manurung (2005) tingkat pendidikan dan tingkat konsumsi memiliki korelasi yang positif. Semakin tinggi pendidikan seseorang, maka pengeluaran konsumsi juga akan semakin tinggi. Hal ini didasarkan pada tingkat pendidikan yang tinggi akan berdampak pada peningkatan pendapatan dan kesejahteraan keluarga, dimana seiring peningkatan kesejahteraan, maka tingkat konsumsinya juga akan mengalami peningkatan.

\section{c. Jenis Pekerjaan}

Bekerja adalah salah satu kegiatan yang dilakukan secara teratur dalam jangka waktu tertentu dengan tujuan mendapatkan penghasilan. Secara umum jenis pekerjaan akan membedakan tingkat pendapatan dan dapat menggambarkan kondisi ekonomi sebuah keluarga. Pada penelitian ini jenis pekerjaan yang akan dijabarkan adalah pekerjaan dari responden.

Berdasarkan Tabel 6, untuk data jenis pekerjaan dapat dilihat bahwa 9 orang (30 persen) bekerja sebagai PNS, 2 orang wiraswasta (6,66 persen), 7 orang wirausaha (23,33 persen), 11 orang Ibu rumah tangga (36,66 persen), dan sisanya 1 orang bekerja sebagai Dokter gigi (3,33 persen). Sebagian besar responden merupakan Ibu rumah tangga, posisinya sebagai anggota keluarga yang menerima penghasilan dari suami sebagai kepala keluarga. Penghasilan tersebut digunakan untuk membeli kebutuhan pangan keluarga, termasuk diantaranya adalah kebutuhan untuk konsumsi cabai rawit.

Menurut Rosidi dan Sulistyowati (2012), pekerjaan tingkat tinggi akan menghasilkan pendapatan yang tinggi, peningkatan pendapatan akan meningkatkan pula perhatian dan kesadaran terhadap kandungan gizi makanan yang akan dikonsumsi sehingga kualitas konsumsi pangan meningkat. Termasuk didalamnya konsumsi sayur -mayur dan rempah berupa cabai rawit.

Tabel 6. Jenis Pekerjaan Responden Konsumen Cabai Rawit di kota Mataram

\begin{tabular}{lcc}
\hline Pekerjaan & Jumlah & Presentase (\%) \\
\hline PNS & 9 & 30 \\
Wiraswasta & 2 & 6,66 \\
Wirausaha & 7 & 23,33 \\
Ibu rumah tangga & 11 & 36,66 \\
Dokter & 1 & 3,33 \\
\hline Jumlah & 30 & 100
\end{tabular}

Jumlah

Sumber: Data primer (2019) 
Menurut Rosidi dan Sulistyowati (2012), pekerjaan tingkat tinggi akan menghasilkan pendapatan yang tinggi, peningkatan pendapatan akan meningkatkan pula perhatian dan kesadaran terhadap kandungan gizi makanan yang akan dikonsumsi sehingga kualitas konsumsi pangan meningkat. Termasuk didalamnya konsumsi sayur - mayur dan rempah berupa cabai rawit.

\section{d. Jumlah Anggota Keluarga}

Jumlah anggota keluarga juga dapat berpengaruh pada seberapa banyak pembelian Cabai rawit di Kota Mataram.

Tabel 7. Jumlah Angota Keluarga Responden Konsumen Cabai Rawit di kota Mataram

\begin{tabular}{lcc}
\hline Uraian & Jumlah & Presentase (\%) \\
\hline 1 anggota & 0 & 0 \\
2 anggota & 7 & 23,23 \\
3 anggota & 14 & 46,67 \\
$\geq 4$ anggota & 9 & 30 \\
\hline Jumlah & 30 & 100 \\
\hline
\end{tabular}

Sumber: Data primer (2019)

Berdasarkan Tabel 7, tidak ada dari responden yang beranggotakan 1 orang (0 persen), sedangkan responden dengan 2 anggota keluarga terdapat sebanyak 7 responden (23,33 persen). Pada penelitian ini, responden yang memiliki anggota keluarga sebanyak 3 anggota merupakan karakterisktik responden yang paling banyak, yaitu sebanyak 14 responden (46,67 persen), sedangkan responden dengan jumlah anggota $\geq 4$ anggota terdapat sebanyak 9 responden (30 persen). Hasil ini menunjukkan sebagian besar responden beranggotakan 3 anggota keluarga. Hasil ini sesuai dengan penelitian Yanti et al. (2019), dimana terdapat korelasi positif antara jumlah anggota keluarga dan permintaan cabai rawit.

\section{e. Jenis Kelamin}

Karakteristik jenis kelamin merupakan jenis karakteristik responden yang digunakan untuk melihat seberapa banyak persentase konsumen cabai rawit berdasarkan jenis kelamin.

Tabel 8. Jenis Kelamin Responden Konsumen Cabai Rawit di kota Mataram

\begin{tabular}{lcc}
\hline Jenis Kelamin & Jumlah & Presentase (\%) \\
\hline Laki-laki & 0 & 0 \\
Perempuan & 30 & 100 \\
\hline Jumlah & 30 & 100
\end{tabular}

Sumber: Data primer (2019)

Berdasarkan Tabel 8, responden dalam penelitian ini secara keseluruhan adalah berjenis kelamin perempuan dengan persentase 100 persen dan $36,66 \%$ dari responden adalah ibu rumah tangga.

Temuan ini menunjukkan bahwa rata-rata konsumen yang membel langsung cabai rawit di pasar merupakan konsumen perempuan. Para ibu rumah tangga biasanya memiliki peran menyiapkan bahan makanan dan sayuran untuk diolah menjadi menu makanan di rumah.

Menurut penelitian Herminda dan Prihatini (2016), bila dilihat menurut jenis kelamin, konsumsi sayur termasuk cabai rawit di dalamnya hampir sama antara laki-laki dan perempuan ( 94,8 persen). Namun untuk konsumsi buah, lakilaki lebih sedikit (31,0 persen) dibandingkan perempuan (35,5 persen).

\subsection{Faktor-faktor yang Mempengaruhi Permintaan Cabai rawit}

Fungsi permintaan cabai rawit di Kota Mataram menggunakan persamaan regresi linear berganda bentuk logaritma natural dalam pengolahannya. Untuk pembahasan permintaan cabai rawit di kota mataram dapat dilihat pada Tabel 9.

Berdasarkan hasil pada Tabel 9 dapat dibuat persamaan regresi berganda untuk model permintaan cabai rawit di Kota Mataram sesuai dengan model persamaan yang dijabarkan pada metode penelitian, maka persamaan regresinya adalah :

\section{$Y=-11,7580+1,0482 X_{1}-3,10 E-05 X_{2}-0,0033 X_{3}-0,0006 X_{4}-0,0357 X_{5}+$ $0,01071 X_{6}$}

Berdasarkan hasil uji regresi linier berganda, maka pengaruh masing masing variabel bebas terhadap permintaan cabai rawit di Kora Mataram, Provinsi Nusa Tengga barat sebagai berikut :

\section{a. Pengaruh Harga Cabai Rawitterhadap Permintaan Cabai Rawit}

Berdasarkan Tabel 9, variabel harga cabai rawit $\left(\mathrm{X}_{1}\right)$ dihasilkan koefisien bernilai positif sebesar 1,0482. Tanda positif ini menunjukan hubungan yang searah antara harga cabai rawit dengan jumlah permintaan cabai rawit. Tanda positif ini bermakna jika ada kenaikan harga cabai rawit maka akan terjadi peningkatan permintaan cabai rawit. Berdasarkan hasil regresi pada Tabel 9, variabel harga cabai rawit mempunyai nilai yang signifikan, dibuktikan dengan nilai $p$-value untuk variabel harga cabai rawit sebesar 0,000 . Nilai yang diperoleh tersebut lebih kecil dari taraf nyata 0.05 , sehingga harga cabai rawit mempunyai pengaruh nyata atau signifikan terhadap permintaan cabai rawit di Kota Mataram pada taraf nyata 5 persen. Hasil penelitian ini tidak sesuai dengan teori permintaan yang menyatakan bahwa harga suatu komoditas memiliki pengaruh yang negatif, dimana ketika harga suatu komoditas naik maka permintaan komoditas tersebut akan mengalami penurunan (Elvira, 2015). Ketidaksesuaian dengan teori ini dikarenakan bagi masyarakat khususnya masyarakat di Kota Mataram yang memiliki selera maknan dengan rasa pedas, komoditas cabai rawit merupakan bahan baku utama yang sehari-hari dijadikan bahan dasar dalam campuran setiap masakan olahan. Sehingga ketersediaan komoditas cabai rawit harus selalu ada.

Cabai rawit meruapkan jenis tanaman yang dikenal secara luas di dunia sebagai rempah-rempah penting (Hakim et al. 2015), tanaman ini digunakan untuk memperkuat sensasi pedas dan digunakan sebagai bahan bumbu masakan Semakin tinggi manfaat yang bisa di dapat dari menkonsumsi cabai rawit, serta di dukung dengan komoditas cabai rawit sudah dikenal secara luas menjadikan cabai rawit menjadi komoditas yang memiliki tingkat permintaan yang tinggi.

Cabai rawit merupakan salah satu barang kebutuhan sehari-hari, sehingga saat terjadi peningkatan harga, konsumen akan tetap membeli cabai rawit untuk memenuhi kebutuhannya. Namun hasil penelitian ini berbeda dengan penelitian Yanti et al. (2019) yang menyatakan bahwa harga cabai rawit tidak berpengaruh signifikan terhadap permintaan cabai rawit di Kota Denpasar pada taraf nyata 95 persen. Perbedaan ini dikarenakan dalam penelitian tersebut pada model yang di analisis terdapat variabel dummy sebagai responden (konsumen) yang suka dengan cabai rawit $(\mathrm{D}=1)$ dan konsumen yang tidak suka dengan cabai rawit $(\mathrm{D}=0)$.

\section{b. Pengaruh harga cabai rawit organik terhadap permintaan cabai rawit}

Berdasarkan tabel 9, variabel harga cabai rawit organik $\left(\mathrm{X}_{2}\right)$ memiliki nilai koefisien bernilai negatif sebesar -3,10E-05. Tanda negatif ini menunjukan hubungan yang berlawanan antara harga cabai rawit organik dengan jumlah permintaan cabai rawit. Berdasarkan Uji T-statistik pada hasil regeresi menunjukkan variabel Harga Cabai rawit organik mempunyai nilai yang $p$-value sebesar 0,9709 . Nilai yang dimiliki tersebut lebih besar dari 0.05 , Sehingga harga cabai rawit organik tidak mempunyai pengaruh nyata atau tidak signifikan terhadap permintaan cabai rawit di Kota Mataram dengan taraf nyata 5 persen. Meski cabai rawit organik ini bersifat sebagai barang substitusi tetapi tidak memiliki karakteristik yang sama dengan cabai rawit biasa. Cabai rawit organik memiliki harga yang relatif lebih mahal dibandingkan cabai rawit biasa. Berdasarkan penelusuran lapangan, harga cabai rawit organik sebesar Rp. $100.000 / \mathrm{Kg}$, jauh lebih mahal jika dibandingkan dengan harga cabai rawit biasa sebesar Rp 55.000/Kg. Hal ini menjadikan dinamika harga cabai rawit organik tidak menjadi pertimbangan bagi konsumen untuk membeli cabai rawit biasa. Hal ini sejalan dengan apa yang dikatakan Ponidi (2020) bahwa dinamika harga cabai rawit organik tidak berpengaruh pada harga cabai di pasaran.

\section{c. Pengaruh harga cabai merah besar terhadap permintaan cabai rawit}

Berdasarkan tabel 9, koefisien regresi untuk variabel hargai cabai merah besar $\left(\mathrm{X}_{3}\right)$ bernilai negatif sebesar $-0,003$. Tanda negatif ini menunjukan pengaruh yang berlawanan antara harga cabai merah besar dengan permintaan cabai rawit. Artinya jika harga cabai merah besar naik, maka akan ada penurunan permintaan cabai rawit. Temuan ini didukung oleh penelitian Yanti et al. (2019) yang menganalisis pengaruh negatif antara harga cabai merah besar dengan permintaan cabai rawit. Biasanya cabai merah besar dikombinasikan dengan cabai rawit untuk membuat aneka sambal dan masakan olahan rumah tangga Berdasarkan tabel 9, Harga Cabai merah besar mempunyai $p$-value sebesar 0,7938 . Nilai yang diperoleh tersebut lebih besar dari 0.05 , Sehingga harga cabai merah besar tidak mempunyai pengaruh nyata atau tidak signifikan terhadap permintaan cabai. Hasil penenlitian ini didukung hasil penelitian Yanti et al. (2019) menyatakan bahwa harga cabai merah besar tidak berpengaruh signifikan terhadap permintaan cabai rawit di Kota Denpasar pada taraf nyata 5\%.

\section{d. Pengaruh harga bawang merah terhadap permintaan cabai rawit}

Berdasarkan tabel 9, koefisien regresi untuk harga bawang merah $\left(\mathrm{X}_{4}\right)$ bernilai negatif $-0,000635$. Tanda negatif ini menunjukan pengaruh yang berlawanan antara harga bawang merah dengan permintaan cabai rawit. Artinya jika harga bawang merah naik, maka akan ada penurunan permintaan cabai rawit. Harga bawang merah mempunyai nilai p-value sebesar 0,9582. Nilai yang diperoleh tersebut lebih besar dari 0.05, Sehingga harga bawang merah dinyatakan tidak mempunyai pengaruh nyata atau tidak signifikan terhadap permintaan cabai rawit di Kota Mataram pada taraf nyata 5 persen. Hasil penelitian ini sejalan dengan Hasil penelitian Yanti et al. (2019) yang menyatakan bahwa harga bawang merah tidak berpengaruh signifikan terhadap permintaan cabai rawit di Kota Denpasar pada taraf nyata 5 persen.

\section{e. Pengaruh jumlah anggota keluarga terhadap permintaan cabai rawit}

Berdasarkan tabel 9, koefisien regresi untuk jumlah anggota keluarga $\left(\mathrm{X}_{5}\right)$ bernilai positif sebesar 0,035797 . Tanda positif ini menunjukan pengaruh yang searah antara variabel jumlah anggota keluarga dengan variabel permintaan cabai rawit. Artinya jika jumlah anggota keluarga bertambah satu orang, maka akan ada peningkatan permintaan cabai rawit. Hasil ini menujukan bahwa semakin banyak jumlah anggota keluarga maka jumlah permintaan terhadap cabai rawit akan semakin meningkat. Variabel jumlah anggota keluarga mempunyai $p$-value sebesar 0,0215 . Nilai $p$-value tersebut lebih kecil dari 0.05 . Artinya variabe 
jumlah anggota keluarga mempunyai pengaruh nyata atau signifikan terhadap permintaan cabai rawit di Kota Mataram pada taraf nyata 5 persen. Hasil penelitian ini sejalan dengan hasil penelitian Yanti et al. (2019) yang menyatakan bahwa jumlah anggota keluarga berpengaruh signifikan terhadap permintaan cabai rawit di Kota Denpasar. Kesamaan hasil penelitian ini menunjukkan hampir disetiap daerah semakin banyak jumlah anggota keluarga, maka permintaan cabai rawit akan mengalami peningkatan. Temuan ini juga menunjukkan bahwa masyarakat Kota Mataram menyukai makanan berbahan dasar cabai rawit.

\section{f. Pengaruh pendapatan keluarga terhadap permintaan cabai rawit}

Berdasarkan hasil analisis regresi pada tabel 9, koefisien regresi untuk variabel jumlah pendapatan keluarga $\left(\mathrm{X}_{6}\right)$ bernilai positif sebesar 0,010724 Tanda positif ini menunjukkan hubungan yang searah antara pendapatan dengan permintaan cabai rawit. Temuan ini tentu sejalan dengan teori ekonomi yang berkembang sejak dahulu, dimana menurut Teori Konsumsi John Maynard Keynes menyatakan bahwa manusia sudah pasti secara alamiah dan berdasarkan rata-rata akan meningkatkan konsumsi ketika pendapatan mereka naik, tetapi tidak sebanyak kenaikan pendapatan mereka (Mankiw, 2007). Hal ini didasarkan pada tingkat pendidikan yang tinggi akan berdampak pada peningkatan pendapatan dan kesejahteraan keluarga. Seiring dengan peningkatan kesejahteraan, maka tingkat konsumsinya juga akan mengalami peningkatan.

Secara statistik, Variabel pendapatan keluarga mempunyai nilai $p$-value sebesar 0,0536 . Nilai $p$-value tersebut lebih besar dari 0.05 , sehingga variabe pendapatan keluarga tidak berpengaruh nyata atau tidak signifikan terhadap permintaan cabai rawit di Kota Mataram pada taraf nyata 5 persen. Hasi penelitian ini didukung dengan hasil penelitian Firnando et al. (2020) yang menyatakan bahwa variabel pendapatan tidak memiliki pengaruh pada permintaan cabai di Kabupaten Bungo.

Tabel 9. Hasil Analisis Regresi Linier Berganda

\begin{tabular}{|c|c|c|c|c|}
\hline Variabel & Koefisien & Std. Error & t-hitung & p-value \\
\hline Konstanta & $-11,75808$ & 0,201098 & $-58,46944$ & 0,0000 \\
\hline Harga Cabai Rawit $\left(\mathrm{X}_{1}\right)$ & 1,048236 & 0,011100 & 94,43905 & $0,0000^{*}$ \\
\hline $\begin{array}{l}\text { Harga Cabai rawit } \\
\text { Organik }\left(\mathrm{X}_{2}\right)\end{array}$ & $-0,0000310$ & 0,000841 & $-0,036902$ & 0,9709 \\
\hline $\begin{array}{l}\text { Harga Cabai Merah Besar } \\
\left(\mathrm{X}_{3}\right)\end{array}$ & $-0,003346$ & 0,012654 & $-0,264445$ & 0,7938 \\
\hline $\begin{array}{l}\text { Harga Bawang merah } \\
\left(\mathrm{X}_{4}\right)\end{array}$ & $-0,000635$ & 0,011986 & $-0,052940$ & 0,9582 \\
\hline $\begin{array}{l}\text { Jumlah Anggota Keluarga } \\
\left(\mathrm{X}_{5}\right)\end{array}$ & 0,035797 & 0,014505 & 2,467849 & $0,0215^{*}$ \\
\hline Pendapatan Keluarga $\left(\mathrm{X}_{6}\right)$ & 0,010724 & 0,005271 & 2,034612 & 0,0536 \\
\hline $\begin{array}{l}\text { R-Square }\left(R^{2}\right)=99,8 \\
\text { persen }\end{array}$ & $\begin{array}{l}\text { Prob-F- } \\
\text { Statistic }\end{array}$ & $=0,000$ & F-hitung $=$ & 2096,668 \\
\hline
\end{tabular}

${ }^{*}$ Signifikan pada taraf nyata 5 persen

Sumber: Data hasil analisis di E Views-9 (2020)

\section{Simpulan}

Karakteristik konsumen yang mengkonsumsi cabai rawit di Kota Mataram berbeda-beda berdasarkan posisi dalam keluarga, umur, tingkat pendidikan, jumlah anggota keluarga dan gender. Berdasarkan usia, konsumen berada pada rentang usia 15 - 64 tahun, Sedangkan konsumen pada rentang usia $<15$ tahun dan $>64$ tahun dinyatakan tidak ada. Berdasarkan tingkat pendidikan konsumen adalah merupakan lulusan Perguruan Tinggi, SMA, SMP dan SD berturut-turut sebanyak 63,33 persen, 16,66 persen, 13,34 persen dan 6,66 persen. Berdasarkan posisi dalam keluarga terdapat mayoritas konsumen adalah berperan sebagai Ibu rumah tangga sebanyak 36,66 persen, selebihnya berperan sebagai

PNS sebanyak 30 persen, Wiraswasta sebanyak 6,66 persen, Wirausaha 23,33 persen dan Dokter sebanyak 3,33 persen. Berdasarkan jumlah anggota keluarga, mayoritas konsumen cabai rawit memiliki jumlah anggota keluarga sebanyak 3 anggota adalah sebanyak 46,67 persen. Selebihnya konsumen yang memiliki jumlah anggota keluarga sebanyak 1 anggota, 2 anggota dan 4 anggota berturut-turut sebanyak 0 persen, 23,33 persen, dan 30 persen. Berdasarkan gender, seluruh responden berjenis kelamin Perempuan.

Faktor yang berpengaruh terhadap permintaan cabai rawit di kota Mataram diantaranya adalah variabel harga cabai rawit dan variabel jumlah anggota keluarga. Untuk penelitian lebih lanjut sebaiknya analisis pada hasil penelitian diperdalam dengan menggunakan analisis elastisitas dalam model Sebaiknya menggunakan sampel yang lebih banyak dengan memperhatikan proporsional wilayah sampai tingkat kelurahan agar memperoleh data yang lebih akurat.

\section{Pustaka}

Adianto, J dan Fedryansyah, M. 2018. Peningkatan Kualitas Tenaga Kerja dalam Menghadapi Asean Economy Community. Focus: Jurnal Pekerjaan Sosial. 1 (2) ; 77-86.

Amirudin, M.M dan Nurhayati, F. 2014. Hubungan Antara Pendapatan Orang Tua dengan Status Gizi Pada Siswa SDN II Tenggong Rejotangan Tulungagung. Jurnal Pendidikan Olahraga dan Kesehatan. 2 (3) : 564 568.
[BPS] Badan Pusat Statistik Provinsi NTB. 2017. Provinsi NTB Dalam Angka 2017

https://ntb.bps.go.id/publication/2017/08/11/85bf7f9f0d2826ed2a8b2f74/ provinsi - ntb-dalam-angka-2017.html(diakses tanggal 10 November 2019)

[BPS]Badan Pusat Statistik Provinsi NTB.2018. Berita Resmi Statistik Perkembangan Indeks Harga Konsumen/Inflasi Kota Mataram Desember 2017. https://ntb.bps.go.id/pressrelease/2018/01/02/717012/desember2017-kotamataram-inflasi-1-07-persen.html (diakses tanggal 10 November 2019)

[BPS] Badan Pusat Statistik (BPS) Indonesia. 2019. Produksi Tanaman Sayuran Cabai Rawit (Ton) Per Provinsi Tahun 2018. (diakses tanggal 10 November 2019)

Bete, K., dan Taena, W. 2018. Faktor-Faktor yang Mempengaruhi Produksi Usahatani Cabe Rawit Merah di Desa Tapenpah Kecamatan Insana Kabupaten Timor Tengah Utara. Agrimor : Jurnal Agribisnis Lahan Kering. 3 (1): 7-9.

Elvira, R. 2015. TEORI PERMINTAAN (Komparasi Dalam Perspektif Ekonomi Konvensional Dengan Ekonomi Islam). ISLAMIKA: Jurnal-Jurnal Ilmu Keislaman. 15 (1): 47-60

Firnando, H., Afrianto, E., dan Pitriani. 2020. Analisis Faktor-Faktor yang Mempengaruhi Permintaan Cabai Merah di Pasar Bungur Kabupaten Bungo. AGRITURE: Jurnal Agribisnis Future. Vol 2 No 1.

Gujarati, D.N. \& Porter, D.C. 2009. Basic Econometrics. McGraw-Hill Irwin

Hakim, L., Batoro, J., \& Sukenti, K. 2015. Etnobotani Rempah-Rempah di Dusun Kopen Dukuh, Kabupaten Banyuwangi. Jurnal Pembangunan dan Alam Lestari. 6 (2) : 133-142.

Hermina, H., dan Prihatini, S. 2016. Gambaran Konsumsi Sayur dan Buah Penduduk Indonesia Dalam Konteks Gizi Seimbang: Analisis Lanjut Survei Konsumsi Makanan Individu (SKMI) 2014. Buletin Penelitian Kesehatan. 44 (3) : $205-218$.

Kementrian Pertanian. 2017. Pengembangan Tanaman Hortikultura dan Ketahanan Terhadap Hama dan Penyakit. Indonesia.

Mankiw, N.G. 2006. Principles of Economics, Pengantar Ekonomi Mikro. Jakarta: Salemba Empat

Maulana, F.D. 2015. Potensi Jamur Asal Rizosfer Tanaman Cabai Rawit (Capsicum frutescens L.) Sehat dari Desa Bumbungan Kecamatan Banjarangkan Kabupaten Klungkung dalam Upaya Mengendalikan Penyakit Layu Fusarium Secara In Vitro. Jurnal Agroekoteknologi Tropika. 5 (2): 151-159.

Noviasari, T. 2014. Permintaan Konsumen Rumah Tangga Terhadap Cabai Merah di Kecamatan Coblong Kota Bandung.[Skripsi]. Bogor : Institu Pertanian Bogor. https://repository.ipb.ac.id/bitstream/handle/123456789/69255/H14tno.p df? sequence $=1 \&$ isAllowed $=y$ (diakses 25 Mei 2020).

Ponidi. 2020. Petani Bateng Beralih ke Tanaman Organik. Sumber https:/www.balipost.com/news/2020/01/23/100360/Petani-di-PetangBeralih-ke...html [diakses 28 Juni 2020]

Priyadi. 2017. Pengembangan Budidaya Tanaman Hortikultura di Indonesia.

Rahardja, Prathama. Manurung, Mandala. 2005. Teori Ekonomi Makro: Suatu Pengantar, Edisi Ketiga, Jakarta: Lembaga Penerbit Fakultas Ekonomi Universitas Indonesia

Rosidi, A., dan Sulistyowati, E. 2012. Peran Pendidikan Dan Pekerjaan Ibu Dalam Konsumsi Sayur Anak Prasekolah. Jurnal Gizi Universitas Muhammadiyah Semarang. 1 (1) : 1-8.

Septiadi, D., dan Joka, U. 2019. Analisis Respon dan Faktor-Faktor yang Mempengaruhi Permintaan Beras Indonesia. Agrimor : Jurnal Agribisnis Lahan Kering. 4 (3): 42-44.

Setiadi. 2006. Bertanam Cabai. Jakarta: Penebar Swadaya

Sugiyono. 2006. Metode Penelitian Kuantitatif, Kualitatif dan R \& D. Bandung: Alfabeta

Yanti, N.M.S.W., Susrusa, K.B., Listiadewi, I.A. 2019. Faktor-faktor yang Mempengaruhi Permintaan Konsumen terhadap Cabai Rawit di Kota Denpasar Provinsi Bali. Jurnal Agribisnis dan Agrowisata. 8 (2) : 165-174.

Warisno, K.D. 2010. Peluang Usaha dan Budidaya Cabai. PT Gramedia Pustaka Utama: Jakarta

Zaini, A. 2014. Volatilitas Harga dan Respon Produksi Cabe di Pulau Lombok. Jurnal Agrimansion. Vol 15 (1): 31-47. 